\title{
HUBUNGAN PENGETAHUAN DAN PENGALAMAN PADA SIKAP DAN PENGARUH SIKAP PADAPERILAKU PEMBELIAN
}

\author{
Arsy Nur Fadilah ${ }^{1}$, Any Suryantini², Dwidjono Hadi Darwanto ${ }^{3}$ \\ ${ }^{1,2,3}$ Program Studi Manajemen Agribisnis,Fakultas Pertanian, Universitas Gadjah Mada, \\ Email: arsyarsymedes@gmail.com ${ }^{1}$, any.suryantini@ugm.ac.id ${ }^{2}$, dwidjono.hadidarwanto@ugm.ac.id ${ }^{3}$
}

\begin{abstract}
ABSTRAK
Penelitian ini bertujuan untuk megetahui (1) pengaruh pengetahuan dan pengalaman konsumen terhadap sikap konsumen dalam pembelian brownies Cokro Tela, (2) pengaruh sikap konsumen terhadap perilaku pembelian brownies Cokro Tela yang berbahan baku mocaf. Responden merupakan konsumen brownies Cokro Tela. Responden dalam penelitian ini berjumlah 80 orang yang diambil secara Purposive sampling.Metode penelitian yang digunakan yaitu metode survei. Model SEM-PLS digunakan untuk menganalisis diagram jalur antarasatu variabellaten ke variabel laten lainnya dan variabel laten ke indikatornya. Variabel laten meliputi pengetahuan, pengalaman, sikap dan perilaku pembelian pada konsumen. Hasil penelitian menunjukan bahwa pengetahuan tidak berpengaruh secara signifikan terhadap sikap, sedangkan pengalaman berpengaruh siginifikan terhadap sikap dan sikap berpengaruh signifikan terhadap perilaku pembelian brownies Cokro Tela.
\end{abstract}

Kata kunci : mocaf, brownies Cokro Tela, sikap, perilaku pembelian

\section{PENDAHULUAN}

Industri makanan dan minuman terus menunjukan perkembangan yang positif dan memberikan konstribusi yang lebih besar bagi pertumbuhan ekonomi nasional. Pada periode Januari - September 2014, kontribusi industri makanan dan minuman secara kumulatif terhadap PDB non migas sebesar $36,85 \%$, yang merupakan pertumbuhan tertinggi pada cabang industri non-migas dengan persentase pertumbuhan mencapai $8,80 \%$. Selain itu, industri makanan dan minuman dapat menyerap tenaga kerja langsung lebih dari 1,6 juta orang pada tahun 2014 (Hartono, 2015).

Industri makanan dan minuman menempati posisi pertama dengan jumlah 4.023 UKM, disusul industri olahan dari kayu (3.987 UKM), industri anyaman (2.266 UKM), industri gerabah/keramik (1.828 UKM), serta industri konveksi dan tenunan (1.779 UKM). Data ini membuktikan potensi UKM sebagai penggerak perekonomian masyarakat sangat besar. Hal Ini merupakan indikator bahwa industri makanan dan minuman yang banyak dikerjakan UKM memiliki potensi besar untuk dikembangkan.

Dibalik kontribusi UMKM yang cukup baik terhadap perekonomian nasional, ternyata sektor ini masih menyimpan segudang permasalahan yang sangat mendasar. Masalah rendahnya produktivitas UKM selama ini masih terjadi. Salah satu kendala yang dihadapi UKM adalah pemasaran yang lemah dan keterbatasan informasi pasar (BPS, 2016). Menurut Utama (2017) pelaku UKM kesulitan untuk 
menjangkau luas penjualan produk. Hal ini dapat dikarenakan lemahnya akses informasi pada pelaku UKM (Babeh, 2016).

Pelaku UKM kurang mencari informasi mengenai kompetitor bisnis dan konsumen (Babeh, 2016). Sebuah perusahaan yang selalu update berbagai informasi di lapangan termasuk informasi tentang konsumen akan mampu meminimalisie kerugian. Informasi yang didapatkan akan dengan mudah memprediksi kebutuhan yang menjadi trend pasar. Pengetahuan akan trend pasar akan mampu membuat sebuah strategi bisnis termasuk strategi pemasaran untuk meningkatkan keuntungan.

Menurut Taib \& Roswita (2018)diferensiasi produk merupakan salah satu terobosan yang biasa dilakukan oleh pemilik industri untuk meningkatkan keuntungan. Putra, Basri, \& Pailis (2017)menyatakan bahwa untuk pengembangan industri makanan diperlukan diferensiasi produk.Menurut Sahetapy (2013)diferensiasi produk berpengaruh secara simultan terhadap keputusan pembelian konsumen. Diferensiasi produk yang lebih menarik akan memudahkan konsumen untuk memilih produk sesuai dengan keinginannya, sehingga akan membangun loyalitas konsumen terhadap produk. Jika perusahaan dapat mengetahui jenis produk yang dibutuhkan oleh konsumen maka hal tersebut dapat menjadi strategi pemasaran untuk meningkatkan keuntungan perusahaan. Pelaku usaha selama ini kurang mendapatkan informasi mengenai macam diferensiasi produk dan terbatasnya informasi mengenai konsumen.

Di Yogyakarta sudah ada perusahaan skala industri menengah keatas yang memproduksi olahan berbahan mocaf yaitu Cokro Tela. Cokro Tela merupakan produsen yang mengolah ketela menjadi bahan utama sebuah makanan berkelas yaitu Brownies Tela. Dalam upaya memasarkan produk secara luas dan meningkatkan skala usaha, perusahaan perlu memahami selera dan kebutuhan konsumen. Salah satu fungsi sikap adalah mampu memberikan nilai-nilai yang ada pada diri konsumen dan keinginan konsumen terhadap produk sehingga perusahaan dapat memahami selera dan kebutuhan konsumen.

\section{METODE PENELITIAN}

Metode yang digunakan dalam penelitian ini adalah metode penelitian survei. Penelitian survei ini menggunakan survei analisis yaitu mempelajari dua atau lebih variabel untuk menguji hipotesis dan menjelaskan mengapa situasi itu ada. Penelitian ini memilih sejumlah responden sebagai sampel dan memberikan kuesioner yang sudah baku. Variabel yang diteliti meliputi variabel pengetahuan dan pengalaman yang akan mempengaruhi variabel sikap dan variabel sikap akan mempengaruhi perilaku pembelian.

Analisis dalam penelitian ini menggunakan medelStructural Equation Modelling-Partial Least Square (SEM-PLS). Manurut Abdillah \& Hartono (2015)Partial Least Square Path Modeling (PLSPM) adalah analisis persamaan struktural (SEM) berbasis varian yang secara simultan dapat melakukan pengujian model pengukuran sekaligus pengujian model struktural. Dalam penelitian ini dilakukan dua pengujian model yaitu pengujian model pengukuran dan model struktural. 
Sampel dilakukan secara purposive sampling yaitu teknik pemilihan sampel tidak memiliki data mengenai populasi sehingga responden yang dipilih adalah responden yang sedang membeli dan sebelumnya pernah mencoba produk brownies Cokro Tela berbahan mocaf.Penelitian ini dilakukan kepada 80 konsumen brownies Cokro Tela di Jl. Hoscokroaminoto No 97.

\section{Model Pengukuran}

Model pengukuran menjelaskan hubungan antara variabel indikator dengan variabel laten. Model pengukuran dalam penelitian ini terdapat 4 pengukuran yaitu : (1) pengukuran pengetahuan, (2) pengukuran pengalaman, (3) pengukuran sikap, dan (\$) pengukuran perilaku pembelian. Adapun model pengukuran dapat dijelaskan sebagai berikut:

Diduga variabel laten pengetahuan $\left(\xi_{1}\right)$ dipengaruhi oleh 5 indikator meliputi : indikator berbahan mocaf dan terigu $\left(\mathrm{X}_{1.1}\right)$, indikator harga $\left(\mathrm{X}_{2.1}\right)$, indikator varian brownies $\left(\mathrm{X}_{3.1}\right)$, indikator kemudahan akses informasi $\left(\mathrm{X}_{4.1}\right)$, dan indikator kemudahan akses tempat pembelian $\left(\mathrm{X}_{51 . \mathrm{a}}\right)$. Hal ini dapat dijelaskan dalam persamaan sebagai berikut :

$\xi_{1}=X_{1.1}+X_{2.1}+X_{3.1}+X_{4.1}+X_{5.1}$

Diduga variabel laten pengalaman $\left(\xi_{2}\right)$ dipengaruhi oleh 2 indikator yaitu indikator rasa $\left(\mathrm{X}_{1.2}\right)$ dan indikator tekstur $\left(\mathrm{X}_{2.2}\right)$ seperti dalam persamaan sebagai berikut :

$\xi_{2}=X_{1.2}+X_{2.2}$

Variabel laten Sikap $\left(\eta_{1}\right)$ diduga dipengaruhi oleh 3 indikator meliputi : indikator rasa suka karena kualitas yang baik $\left(\mathrm{Y}_{1.1}\right)$, indikator rasa suka karena berbahan baku mocaf $\left(\mathrm{Y}_{2.1}\right)$, dan rasa suka karena dianggap murah $\left(\mathrm{Y}_{3.1}\right)$. Hal ini dapat dijelaskan dalam persamaan sebagai berikut :

$\eta 1=\mathrm{Y}_{1.1}+\mathrm{Y}_{2.1}+\mathrm{Y}_{3.1}$

Variabel laten perilaku pembelian $\left(\eta_{2}\right)$ diduga dipengaruhi oleh 5 indikator yaitu : indikator melakukan pembelian ulang $\left(\mathrm{Y}_{1.2}\right)$, indikator mengatur keuangan untuk membeli kembali $\left(\mathrm{Y}_{2.2}\right)$, indikator mengatur waktu untuk membeli kembali $\left(\mathrm{Y}_{3.2}\right)$, indikator membeli sesering mungkin $\left(\mathrm{Y}_{4.2}\right)$, dan indikator melakukan pembelian atas rekomendasi orang-orang terdekat $\left(\mathrm{Y}_{5.2}\right)$. Hal ini dapat dijelaskan dalam persamaan sebagai berikut :

$\eta_{2}=\mathrm{Y}_{1.2}+\mathrm{Y}_{2.2}+\mathrm{Y}_{3.2}+\mathrm{Y}_{4.2}$

\section{Model Struktural}

Model struktural menjelaskan hubungan antar variabel laten. Model struktural dalam penelitian ini terdapat 2 struktural. Adapun model struktural dapat dijelaskan sebagai berikut :

Diduga variabel laten sikap $\left(\eta_{1}\right)$ dipengaruhi oleh variabel laten pengetahuan $\left(\xi_{1}\right)$ dan Pengalaman $\left(\xi_{2}\right)$ seperti dalam persamaan sebagai berikut :

$\eta_{1}=\xi_{1}+\xi_{2}$

Diduga variabel laten perilaku pembelian $\left(\eta_{2}\right)$ dipengaruhi oleh variabel laten sikap $\left(\eta_{1}\right)$ seperti dalam persamaan sebagai berikut :

$\eta_{2}=\eta_{1}$ 
Persamaan diatas dianalisis dengan menggunakan nilailoading factormeliputibeta $(\beta)$ dan lambang lamda $(\lambda)$. Lambang beta $(\beta)$ menjelaskan besaran hubungan antara variabel laten dengan variabel laten lain, sedangkan lambang lamda $(\lambda)$ menunjukan koefisien regresi sederhana yang menghubungkan variabel laten dengan indikatornya. Nilai loading factoryang digunakan dalam penelitian ini adalah nilai 0,5 . Apabila pada indikator terdapat nilai loading factordi bawah 0,5 maka dilakukan eliminasi pada indikator tersebut. Nilai loading factor di bawah 0,5 menunjukan bahwa indikator tidak dapat menjelaskan variabel latennya sehingga perlu di eliminasi.Selanjutnya, bila semua nilai loading factor sudah memenuhi kriteria yaitu nilai loading factor $>0,5$, maka dapat dilanjutkan dengan analisis berikutnya.Analisis tersebut dapat digambarkan dalam gambar sebagai berikut :

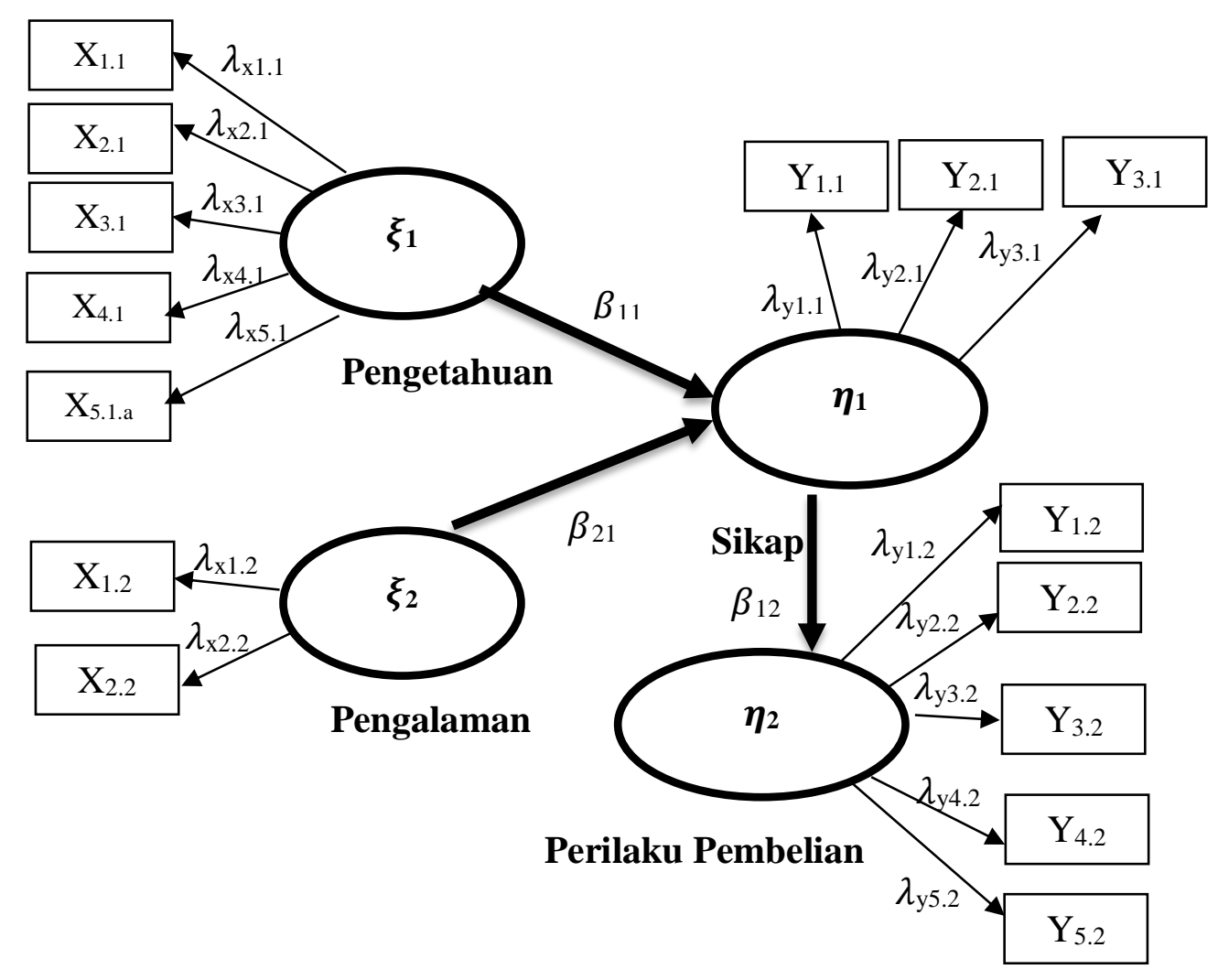

Gambar 1.Hubungan Loading Factor dengan Model Pengukuran dan Model Struktural

\section{Uji Model Pengukuran}

\section{Uji korelasi indikator terhadap variabel laten}

Analisis uji Convergent validity menjelaskan bahwa variabel indikator dari suatu variabel laten seharusnya berkorelasi tinggi. Uji validitas Convergentvaliditydapat dilihat dari nilai loading factor. Skala pengukuran nilai loading factor 0,5-0,6 masih anggap cukup Ghozali dan Latan (2015).

\section{Analisis uji validitas}


Analisis uji validitas dalam SEM-PLS yaitu Discriminant Validity.Discriminant Validity memiliki prinsip bahwa indikator dari variabel laten yang berbeda seharusnya tidak berkorelasi tinggi(Ghozali \& Latan, 2015), sehingga menjadi alat ukur yang tepat untuk menjelaskan variabel latennya. Cara untuk menguji validitas discriminant validity adalah dengan membandingkan akar kuadrat dari AVE setiap variabel laten dengan nilai korelasi antar variabel laten dalam model. Akar kuadrat AVE tiap variabel laten harus lebih besar dari korelasi antar variabel laten dalam model. Hal ini menjelaskan bahwa indikator tidak memiliki korelasi terhadap indikator pada variabel laten yang lain, artinya bahwa indikator tersebut dapat menjadi alat ukur yang tepat dalam mengukur variabel latennya.

\section{Analisis uji reabilitas}

Uji reabilitas atau composite reabilitydilakukan untuk menguji akurasi, konsistensi, dan ketepatan instrumen dalam mengukur konstruk(Ghozali \& Latan, 2015).Menurut Juwono(2015)kontruk adalah konsep yang disusun secara sistematis untuk tujuan tertentu dengan memuat (antara lain) variabel-variabel yang dapat diukur.Dikatakan reliabel artinya dalam beberapa kali uji hasilnya tetap sama, sehingga hasil yang dihasilkan dari konsep penelitian memiliki hasil yang akurat dan konsisten. Uji reabilitas digunakan dengan melihat nilai Cronbach's Alpha atau Composite Reliability > 0.6-0,7 masih dapat diterima (Ghozali \& Latan, 2015).

\section{Uji Model Pengukuran}

\section{Analisis uji korelasi variabel laten}

Selain dilihat dari nilai R-squares, dapat juga dilihat dari perbandingan t-table dan $\mathrm{t}$-statistic. Jika nilai t-statistic lebih tinggi dibandingkan t-table, berarti memiliki pengaruh antara variabel laten eksogen dengan variabel laten endogen. Nilai t-table yang digunakan dalam penelitian ini adalah 1,960, dimana nilai tersebut digunakan pada siginifikasi tingkat kesalahan 0,05. Nilai t-statistic didapat dari hasil analisis aplikasi SamrtPLS ver. 3.0.

\section{Uji kekuatan model struktural}

Pengujian model pengukuran dan struktural digunakan untuk mengetahui seberapa besar kekuatan model untuk dapat digunakan dalam penelitian. Pengujian model dapat dilihat dari nilai RSquare. Apabila nilai R-square 0,75 atau lebih besar dari 0,75 maka model dikatakan kuat. Jika nilai R-square 0,50 atau lebih besar dari 0,50 maka model dikatakan sedang dan jika nilai 0,25 atau lebih besar dari 0,25 maka model dikatakan lemah(Ghozali \& Latan, 2015).

\section{HASIL DAN PEMBAHASAN}

\section{Deskripsi Responden}

Karakteristik responden menggambarakan keadaan responden pada penelitian ini. karakteristik responden meliputi jenis kelamin, usia responden, tingkat pendidikan, jenis pekerjaan dan pendapatan. Responden yang diambil dalam penelitian ini adalah konsumen yang sedang membeli brownies dan sebelumnya pernah mencoba brownies cokro tela berbahan mocaf. 
Tabel 1. Profil Responden

\begin{tabular}{lccc}
\hline \multicolumn{1}{c}{ Uraian } & & Jumlah (orang) & Persen (\%) \\
\hline Jenis Kelamin & Laki-laki & 20 & 25,0 \\
Umur & Perempuan & 60 & 75,0 \\
& 15th-32th & 53 & 66,3 \\
\multirow{5}{*}{ Pendidikan } & 33th-50th & 22 & 27,4 \\
& 51 th-62th & 5 & 6,3 \\
& SMP & 6 & 7,5 \\
Pekerjaan & SMA & 23 & 28,7 \\
& PT(Perguruan Tinggi) & 51 & 63,8 \\
& Pelajar/mahasiswa & 34 & 42,4 \\
& PNS & 4 & 5 \\
Pendapatan & Swasta & 37 & 46,3 \\
& Ibu Rumah Tangga & 5 & 6,3 \\
& <Rp 2.000,000 & 43 & 53,8 \\
& Rp 2.000,000- Rp 4.999.999 & 25 & 31,3 \\
& Rp 5.000,000-Rp 7.999.999 & 5 & 6,3 \\
& Rp 8.000,000-Rp 11.000,000 & 4 & 5,0 \\
& $>$ Rp 11.000,000 & 3 & 3,8
\end{tabular}

\section{Sumber : Data Primer SPSS 11.5}

Berdasarkan hasil penelitian sebagian responden yang membeli brownies berbahan mocaf adalah konsumen yang berjenis kelamin perempuan. Sebagian besar konsumen yang berjenis kelamin perempuan lebih cenderung membeli brownies untuk kepentingan orang lain atau sebuah acara ketimbang untuk dikonsumsi pribadi. Perempuan merupakan sosok figur yang dinilai mampu untuk menentukan jenis makanan yang akan dikonsumsi baik didalam keluarga, acara resmi maupun tidak resmi(Pangan, Densitas, \& Pada, 2014).

Usia rata-rata respondenberumur 21-26 tahun dengan mayoritas tingkat pendidikan perguruan tinggi dan memiliki pendapatan <Rp 2.000,000. Pada usia tersebut responden banyak bekerja dan bersosialisasi dengan teman sebaya dan berinteraksi dengan berbagai media, sehingga cukup mudah untuk menerima dan memahami suatu hal yang baru termasuk brownies berbahan mocaf yang masih menjadi produk baru dalam masyarakat.

\section{Uji Model Pengukuran}

Model pengukuran menjelaskan hubungan antara variabel indikator dengan variabel laten. Indikator dalam penelitian ini terbagi menjadi 4 yaitu (1) indikator variabel laten pengetahuan, (2) indikator variabel laten pengalaman, (3) indikator variabel laten sikap, dan (4) indikator variabel laten perilaku pembelian. Pengujian indikator dapat dilihat dari nilai loading factorharus lebih besar dari 0,5 yang menunjukan indikator tersebut memiliki hubungan terhadap variabel laten. Jika nilai loading factorkurang dari 0,5 maka indikator tersebut harus dieliminasi karna dianggap tidak memiliki 
hubungan atau tidak dapat menjelaskan varibel latennya.Hasil pengujian model pengukuran dapat dijelaskan sebagai berikut :

\section{Uji pengukuran pengetahuan}

Diduga variabel laten pengetahuan $\left(\xi_{1}\right)$ dipengaruhi oleh 5 indikator meliputi : indikator berbahan mocaf dan terigu $\left(\mathrm{X}_{1.1}\right)$, indikator harga $\left(\mathrm{X}_{2.1}\right)$, indikator varian brownies $\left(\mathrm{X}_{3.1}\right)$, indikator kemudahan akses informasi $\left(\mathrm{X}_{4.1}\right)$, dan indikator kemudahan akses tempat pembelian $\left(\mathrm{X}_{51 . \mathrm{a}}\right)$. Hal ini dapat dijelaskan dalam gambar sebagai berikut :

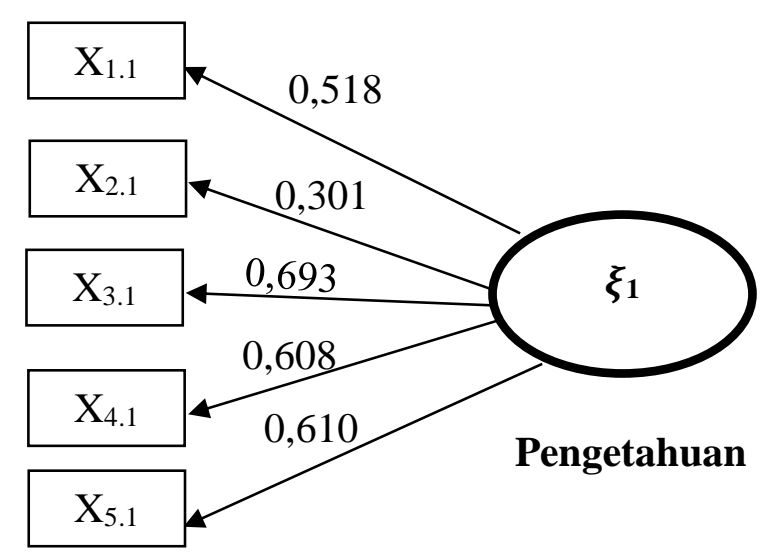

\section{Gambar 2 . Model Pengukuran Pengetahuan}

Hasil model pengukuran pengetahuan menunjukkan bahwa nilai loading factor yang kurang dari 0,5 terdapat pada indikator harga $\left(\mathrm{X}_{2.1}\right)$ sebesar 0,301 . Hal ini menunjukkan bahwa harga tidak dapat menjelaskanvariabel laten pengetahuan, sehingga harus di eliminasi. Hasil dilapangan menjelaskan bahwa responden menganggap harga brownies Cokro Tela berbahan mocaf memiliki harga yang standar tidak jauh berbeda dengan harga brownies pada umumnya, sehingga perlu dieliminasi dan dilakukan modifikasi diagram jalur seperti dalam gambar berikut :

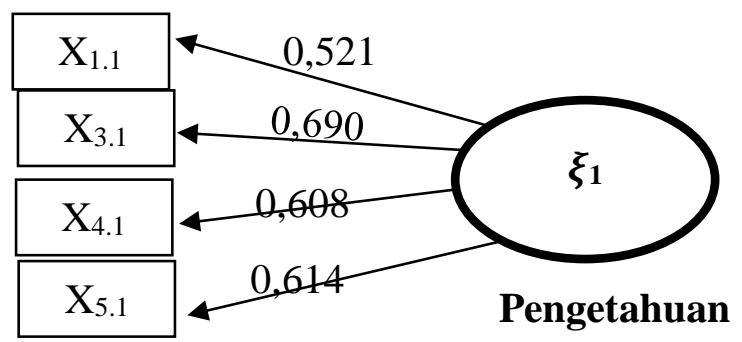

Gambar 3. Model Pengukuran Pengetahuan Setelah Dimodifikasi

Gambar 3 menunjukan bahwa nilai loading factor> 0,5, artinya seluruh indikator dapat menjelaskan variabel laten pengetahuan sehingga model tidak perlu dilakukan modifikasi diagram jalur.

Pada penelitian ini terdapat uji validitas dan reabilitas untuk mengetahui kelayakan alat ukur yang digunakan dan kehandalan instrumen penelitian. Indikator dinyatakan valid apabila nilai akar AVE lebih tinggi dibanding dengan nilai korelasi antar variabel lain. Berdasarakan hasil uji validitas, 
diketahui nilai akar AVE pengetahuan sebesar 0,611 dan nilai korelasi antara variabel pengetahuan dengan variabel lain secara berturut-turut adalah 0,363, 0,526, 0,296. Hal ini berarti nilai akar AVE pengetahuan lebih besar daripada nilai korelasi antar variabel lain, sehingga dapat dikatakan valid. Hal ini menunjukan bahwa seluruh indikator dalam variabel pengetahuan dapat digunakan sebagai alat ukur untuk mengukur pengetahuan konsumen terhadap brownies Cokro Tela berbahan baku mocaf.

Pada uji reabilitas instrumen penelitian dikatakan memiliki kehandalan yang baik apabila memiliki nilai Composite Reliability > 0,6-0,7. Berdasarkan hasil uji reabilitas diketahui nilai Composite reliability variabel laten pengetahuan sebesar $0,903>0,7$ sehingga variabel pengetahuan dapat dikatakan reliabel. Hasil tersebut menjelaskan bahwa kuesioner tentang pengetahuan dalam penelitian ini dipercaya sebagai alat pengumpul data yang akurat karena telah memenuhi kelayakan dan kehandalan instrumen penelitian.

\section{Uji pengukuran pengalaman}

Diduga variabel laten pengalaman $\left(\xi_{2}\right)$ dipengaruhi oleh 2 indikator yaitu indikator rasa $\left(\mathrm{X}_{1.2}\right)$ dan indikator tekstur $\left(\mathrm{X}_{2.2}\right)$. Hal ini dapat dijelaskan dalam gambar sebagai berikut :

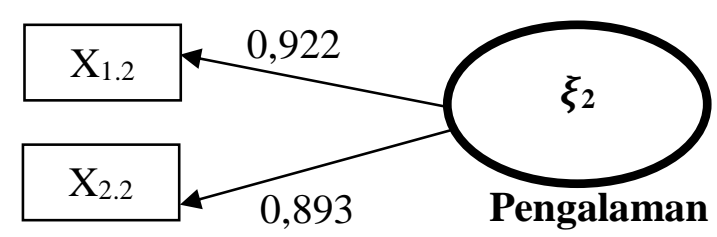

\section{Gambar 4 . Model Pengukuran Pengalaman}

Gambar 4 menunjukan bahwa nilai loading factor sudah memenuhi kriteria yaitu nilai loading factor > 0,5. Hal ini menunjukan bahwa semua indikator dapat menjelaskan variabel laten pengalaman.

Berdasarakan hasil uji validitas, diketahui nilai akar AVE pengalaman sebesar 0,908 dan nilai korelasi antara variabel pengalaman dengan variabel lain secara berturut-turut adalah 0,363, 0,537, 0,703. Hal ini berarti nilai akar AVE pengalaman lebih besar daripada nilai korelasi antar variabel lain, sehingga dapat dikatakan valid. Hal ini menunjukan bahwa seluruh indikator dalam variabel pengalaman dapat digunakan sebagai alat ukur untuk mengukur pengalaman konsumen terhadap brownies Cokro Tela berbahan baku mocaf.

Berdasarkan hasil uji reabilitas diketahui nilai Composite reliability variabel laten pengalaman sebesar 0,883>0,7 sehingga variabel pengalaman dapat dikatakan reliabel. Hasil tersebut menjelaskan bahwa kuesioner tentang pengalaman dalam penelitian ini dipercaya sebagai alat pengumpul data yang akurat karena telah memenuhi kelayakan dan kehandalan instrumen penelitian.

\section{Uji pengukuran sikap}

Variabel laten Sikap $\left(\eta_{1}\right)$ diduga dipengaruhi oleh 3 indikator meliputi : indikator rasa suka karena kualitas yang baik $\left(\mathrm{Y}_{1.1}\right)$, indikator rasa suka karena berbahan baku mocaf $\left(\mathrm{Y}_{2.1}\right)$, dan rasa suka karena dianggap murah $\left(\mathrm{Y}_{3.1}\right)$.Hal ini dapat dijelaskan dalam gambar sebagai berikut : 


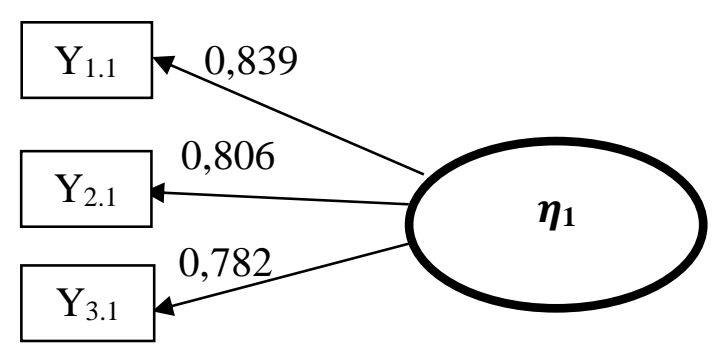

Gambar 5 . Model Pengukuran Sikap

Gambar 5 menunjukan bahwa nilai nilai loading factor sudah memenuhi kriteria yaitu nilai loading factor > 0,5. Halini menunjukan bahwa seluruh indikator dapat menjelaskan dapat menjelaskan variabel sikap.

Berdasarakan hasil uji validitas, diketahui nilai akar AVE sikap sebesar 0,810 dan nilai korelasi antara variabel sikap dengan variabel lain secara berturut-turut adalah 0,703,0,296, 0,589. Hal ini berarti nilai akar AVE sikap lebih besar daripada nilai korelasi antar variabel lain, sehingga dapat dikatakan valid. Hal ini menunjukan bahwa seluruh indikator dalam variabel sikap dapat digunakan sebagai alat ukur untuk mengukur sikap konsumen terhadap brownies Cokro Tela berbahan baku mocaf.

Berdasarkan hasil uji reabilitas diketahui nilai Composite reliability variabel laten sikap sebesar 0,851>0,7 sehingga variabel sikap dapat dikatakan reliabel. Hasil tersebut menjelaskan bahwa kuesioner tentang sikap dalam penelitian ini dipercaya sebagai alat pengumpul data yang akurat karena telah memenuhi kelayakan dan kehandalan instrumen penelitian.

\section{Uji pengukuran perilaku pembelian}

Variabel laten perilaku pembelian $\left(\eta_{2}\right)$ diduga dipengaruhi oleh 5 indikator yaitu : indikator melakukan pembelian ulang $\left(\mathrm{Y}_{1.2}\right)$, indikator mengatur keuangan untuk membeli kembali $\left(\mathrm{Y}_{2.2}\right)$, indikator mengatur waktu untuk membeli kembali $\left(\mathrm{Y}_{3.2}\right)$, indikator membeli sesering mungkin $\left(\mathrm{Y}_{4.2}\right)$, dan indikator melakukan pembelian atas rekomendasi orang-orang terdekat $\left(\mathrm{Y}_{5.2}\right)$. Hal ini dapat dijelaskan dalam gambar sebagai berikut 


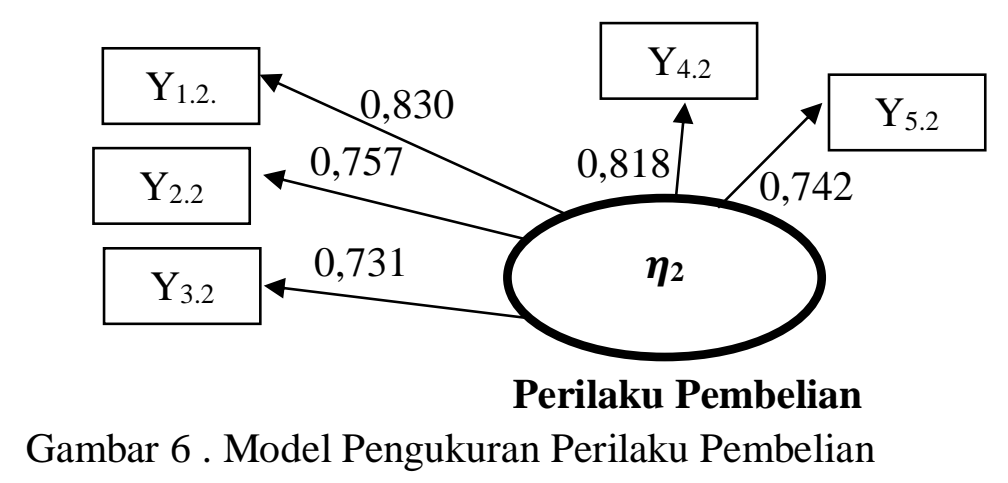

Gambar 6 menunjukan bahwa nilai loading factor sudah memenuhi kriteria yaitu nilai loading factor > 0,5. Halini menunjukan bahwa semua indikator dapat menjelaskan variabel laten perilaku pembelian.

Berdasarakan hasil uji validitas, diketahui nilai akar AVE sikap sebesar 0,776 dan nilai korelasi antara variabel perilaku pembelian dengan variabel lain secara berturut-turut adalah 0,537, 0,526, 0,589. Hal ini berarti nilai akar AVE perilaku pembelian lebih besar daripada nilai korelasi antar variabel lain, sehingga dapat dikatakan valid. Hal ini menunjukan bahwa seluruh indikator dalam variabel perilaku pembelian dapat digunakan sebagai alat ukur untuk mengukur perilaku pembelian konsumen terhadap brownies Cokro Tela berbahan baku mocaf.

Berdasarkan hasil uji reabilitas diketahui nilai Composite reliability variabel laten perilaku pembelian sebesar 0,903>0,7 sehingga variabel sikap dapat dikatakan reliabel. Hasil tersebut menjelaskan bahwa kuesioner tentang perilaku pembelian dalam penelitian ini dipercaya sebagai alat pengumpul data yang akurat karena telah memenuhi kelayakan dan kehandalan instrumen penelitian.

\section{Uji Model Struktural}

Model struktural menjelaskan hubungan antara variabel laten eksogen (independen) dengan variabel laten endogen (dependen) . Variabel laten dalam model struktural terbagi menjadi 2 yaitu : (1) hubungan variabel laten pengetahuan dan pengalaman terhadap variabel laten sikap , (2) hubungan variabel laten sikap terhadap variabel laten perilaku pembelian. Model struktural dapat dijelaskan dalam gambar sebagai berikut : 


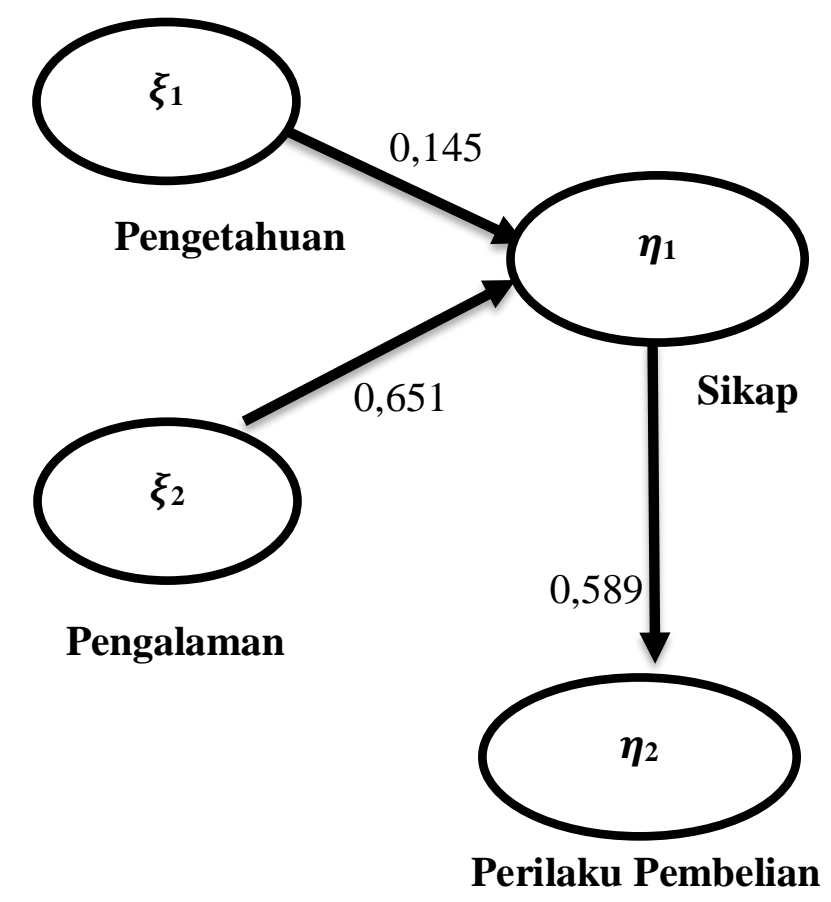

Gambar 7 . Model Struktural

Sesuai pada Gambar 7diketahui variabel laten pengetahuan memiliki nilai koefisien 0,146. Hal ini menunjukkanbahwa pengetahuan tidak dapat menjelaskan sikap dimana nilai koefisiennya $0,146<$ 0,5. Berbeda halnya dengan variabel pengalaman yang menjadi bahan pertimbangan dalam menentukan sikap, dimana pengalaman memiliki nilai koefisien yaitu sebesar 0,650 $>0,5$. Artinya pengalaman dapat menjelaskan sikapyaitusetiap bertambahnya 1 pengalaman pada brownies Cokro Tela berbahan mocaf, maka akan menaikan sikap terhadap brownies tersebut sebesar 0,651 satuan. Hal ini sesuai dengan penelitian yang mengatakan pengalaman konsumen berkontribusi terhadap kepuasan.Pengalaman langsung terhadap produk menjadi faktor penting konsumen membeli produk terutama dalam pengalaman terhadap rasa produk makanan (Xie, Wang, Yang, Wang, \& Zhang, 2015)

Diketahui variabel sikap memiliki nilai koefisien 0,589>0,5 yang artinya sikap dapat menjelaskan variabel perilaku pembelian. Ketika sikap konsumen positif terhadap produk maka akan mempengaruhi kecenderungan dalam perilaku pembelian yang positif. Setiap 1 bertambahnya sikap maka akan menaikan perilaku pembelian sebesar 0,589 satuan. Hal ini sesuai dengan beberapa penelitian dimana menjelaskan bahwa sikap signifikan berpengaruh terhadap pembelian(Xie, Wang, Yang, Wang \& Zhang, 2015). Kepuasan terhadap produk memberikan pengaruh positif terhadap loyalitas sikap terutama loyalitas perilaku untuk membeli kembali (H. J. Lee \& Yun, 2015).

\section{Analisis uji korelasi variabel laten}

Pengujian model struktural dapat dilihat dari perbandingan t-table dan t-statistic. Nilai t-table yang digunakan dalam penelitian ini adalah 1,960, dimana nilai tersebut digunakan pada siginifikasi tingkat kesalahan 0,05. Nilai t-statistic didapat dari hasil analisis aplikasi SamrtPLS ver. 3.0. Analisis korelasi model struktural dapat dilihat pada tabel sebagai berikut : 
Tabel 2.Analisis Korelasi Model Struktural

\begin{tabular}{lc}
\hline Keterangan & T-statistics \\
\hline Pengalaman -> Sikap & 7,120 \\
Pengetahuan-> Sikap & 1,551 \\
Sikap-> Perilaku Pembelian & 8,099 \\
\hline
\end{tabular}

Sumber : Data Primer SmartPLS 3.0

Keterangan : t-statistik >t-value 1,960 menunjukkan signifikan

Tabel 2 menunjukkan t-statistik untuk pengaruh variabel pengetahuan terhadap sikap sebesar $1.551<1,960$, artinya pengetahuan tidak berpengaruh signifikan terhadap sikap konsumen dalam pembelian produk brownies Cokro Tela. Pada variabel pengalaman hasil t-statistik menunjukkan nilai 7,120> 1, 960 yang berarti variabel pengalaman berpengaruh signifikan terhadap variabel sikap. Artinya kenaikan pada pengalaman dapat meningkatkan sikap dalam pembelian. Sebaliknya, penurunan pengaruh pengalaman dapat menurunkan sikap konsumen dalam pembelian. Hasil ini sejalan dengan penelitian yang menjelaskan bahwa pengalaman seseorang dalam mencoba produk dapat meningkatkan loyalitas konsumen terhadap produk dan nama merek (Tu, Yang, \& Ma, 2015).

Pengujian pengaruh sikap terhadap perilaku pembelian brownies Cokro Tela dapat dilihat pada Tabel 2 dimana t-statistik 8.099>1,960 yang berarti sikap signifikan berpengaruh terhadap perilaku pembelian. Hal ini sesuai dengan penelitian yang menjelaskan bahwa persepsi konsumenterhadap atribut makanan mempengaruhi masing-masing dimensi sikap danmengarah ke niat perilaku untuk membeli makanan, sehingga sikap dapat mempengaruhi niat perilaku konsumen untuk membeli makanan. (H.-J. Lee \& Goudeau, 2014). Sikap mempengaruhi secara signifikan terhadap intensitas pembelian dimana salah satu indikator dalam sikap yaitu memiliki persepsi akan kepentingan membeli suatu produk(Yazdanpanah \& Forouzani, 2015).

\section{Uji kekuatan model struktural}

Kekuatan model struktural pada metode PLS diawali dengan melihat R-square. NilaiR-square yang dihasilkan menjelaskan bagaimana pengaruh variabel laten eksogen terhadap variabel laten endogen. Adapun nilai R-square dalam penelitian ini dapat dijelasakan sebagai berikut

Tabel 3. Nilai R-square Pengaruh Variabel Eksogen Terhadap Variabel Endogen

\begin{tabular}{lcr}
\hline Variabel Laten & R Square & Keterangan \\
\hline Pengetahuan & & \\
Pengalaman & & \\
Sikap & 0,513 & Model Moderate \\
Perilaku Pembelian & 0,347 & Model Moderate \\
\hline
\end{tabular}

Sumber : Data Primer SmartPLS 3.0

Keterangan : Kriteria nilai R-Square adalah 0,67 menunjukkan model kuat, 0,33 menunjukkan model moderat dan 0,19 menunjukan model lemah.(Chin dalam Ghozali \&Latan, 2015)

Pada Tabel 3 diketahui nilai R-square variabel laten endogen sikap yaitu sebesar 0,513 dan variabel laten endogen perilaku pembelian sebesar 0,347, yang dapat di interpretasikan bahwa variabilitas konstruk sikap dapat dijelaskan oleh variabilitas konstruk pengalaman sebesar 51\% sedangkan sisanya dijelaskan oleh variabel lain diluar model. 
Hal ini sesuai beberapa penelitian lain yang menyatakan bahwa pengalaman seseorang terhadap rasa, bentuk dan ukuran produk dapat mempengaruhi dalam pembelian (Permadi, 2015). Kurangnya pengalaman sebelumnya tentang makanan akan membuat sulit untuk memastikan kualitas sebuah makanan, sehingga sulit untuk mengevaluasi makanan.Pelanggan sering mengevaluasi makanan dari pengetahuan dan pengalaman masa lalu mereka apakah sesuai dengan harapan dan kinerja yang dirasakan (Chang, Kivela, \& Mak, 2011) . Sebanyak 65\% responden membeli produk organik karena rasanya yang lebih enak. Hal ini menggambarkan bahwa pengalaman langsung terhadap produk memberikan pengaruh besar dalam pembelian (Xie, Wang, Yang, Wang \& Zhang 2015). Kepuasan dari pengetahuan dan pengalaman langsung terhadap produk memberikan pengaruh positif terhadap loyalitas sikap (H.-J. Lee \& Goudeau, 2014)

Nilai R-square variabel laten endogen perilaku pembelian sebesar 0,347 , hal ini menunjukkan bahwa variabilitas konstruk perilaku pembelian dapat dijelaskan oleh variabilitas konstruk sikap sebesar 34\% sedangkan sisanya dijelaskan oleh variabel lain diluar model.

Pada model penelitian ini dihasilkan nilai R-square sikap sebesar 0,513dan perilaku konsumen sebesar 0,347 yang berarti bahwa model termasuk moderate atau cukup, sehingga dapat diartikan bahwa model analisis pengetahuan dan pengalaman cukup menjelaskan analisis pengaruh terhadap sikap konsumen dan sikap dapat menjelaskan pengaruh terhadap perilaku konsumen. Hal ini sesuai dengan penelitian sebelumnya dimana dikatakan sikap signifikan (Thøgersen, de Barcellos, Perin, \& Zhou, 2015).

\section{KESIMPULAN}

Hasil penelitian ini menjelaskan bahwa nilai R-square sikap sebesar 0,513 dan perilaku konsumen sebesar 0,347 yang berarti bahwa model termasuk moderate atau cukup, sehingga dapat diartikan bahwa model analisis pengetahuan dan pengalaman cukup dapat digunakan dalam analisis pengaruh terhadap sikap konsumen dan sikap dapat menjelaskan pengaruh terhadap perilaku konsumen.

Pada model penelitian ini dihasilkan pengetahuan tidak berpengaruh signifikan terhadap sikap konsumen dalam pembelian produk brownies Cokro Tela, sedangkan pengalaman berpengaruh signifikan terhadap sikap konsumen dalam pembelian produk brownies Cokro Tela. Sikap berpengaruh signifikan terhadap perilaku pembelian brownies Cokro Tela. Dimana variabilitas konstruk perilaku pembelian dapat dijelaskan oleh variabilitas konstruk sikap sebesar 34\% sedangkan sisanya dijelaskan oleh variabel lain diluar model.

\section{Ucapan Terimakasih}

Ucapan Terimaksih saya ucapkan kepada pihak terkait dalam penelitian ini baik eksternal maupun internal yang telah membantu penelitian. 


\section{DAFTAR PUSTAKA}

BPS,. (2016). Potensi Besar UKM Industri Makanan-Minuman. Presidenri.Go.Id. Retrieved from presidenri.go.id/berita-aktual/potensi-besar-ukm-industri-makanan-minuman.html

Abdillah, W., \& Hartono, J. (2015). Partial least square (PLS): Alternatif structural equation modeling (SEM) dalam penelitian bisnis. Yogyakarta: Penerbit Andi.

Chang, R. C. Y., Kivela, J., \& Mak, A. H. N. (2011). Attributes that influence the evaluation of travel dining experience: When East meets West. Tourism Management, 32(2), 307316.

Ghozali, I., \& Latan, H. (2015). Partial Least Squares Konsep, Teknik dan Aplikasi Menggunakan Program SmartPLS 3.0 untuk penelitian empiris (2nd ed.). Semarang: Badan Penerbit Universitas Diponegoro.

Hartono. (2015). Kemenperin Dorong Pengembangan Industri Pangan Olahan. Kementrian Perindustrian Republik Indonesia. Retrieved from www.kemenperin.go.id/artikel/10951/Kemenperin-Dorong-Pengembangan-IndustriPangan-Olahan

Juwono, T. (2015). Teori, Konstruk dan Variabel. Surya University. Retrieved from http://blog.complexminds.net/wp-content/uploads/2015/08/Variabel.pdf

Lee, H.-J., \& Goudeau, C. (2014). Consumers' beliefs, attitudes, and loyalty in purchasing organic foods: the standard learning hierarchy approach. British Food Journal, 116(6), 918-930.

Lee, H. J., \& Yun, Z. S. (2015). Consumers' perceptions of organic food attributes and cognitive and affective attitudes as determinants of their purchase intentions toward organic food. Food Quality and Preference, 39(2015), 259-267. https://doi.org/10.1016/j.foodqual.2014.06.002

Pangan, K., Densitas, S., \& Pada, G. (2014). Studi aspek sosial ekonomi dan budaya, konsumsi pangan, serta densitas gizi pada masyarakat kasepuhan ciptagelar jawa barat linda dwi jayanti.

Permadi, R. (2015). Analisis Kepuasan Konsumen Terhadap Atribut Buah Pisang Kepok. Jurnal Social Economic of Agriculture, 4(2), 8-15.

Putra, S., Basri, S., \& Pailis, E. A. (2017). Analisis Industri Pangan Sub Sektor Industri Makanan Ringan Kue Bangkit dan Bolu (dengan Menggunakan Strukture Conduct Performance/scp). Jurnal Online Mahasiswa Fakultas Ekonomi Universitas Riau, 4(1), $558-569$.

Sahetapy, J. P. (2013). Diferensiasi Produk, Strategi Merek, Pengaruhnya Terhadap Keputusan Pembelian Meubel UD Sinar Sakti Manado. Jurnal EMBA: Jurnal Riset Ekonomi, Manajemen, Bisnis Dan Akuntansi, 1(3).

Taib, G., \& Djalal, M. (2014). Evaluation in Component Technology Small Scale Food 
Industry Cluster in West Sumatera. International Journal on Advanced Science, Engineering and Information Technology, 4(2), 60-63.

Taib, G., \& Roswita, R. (2018). Analisis prospek dan kendala pengembangan produk industri pangan lokal di Sumatera Barat. Jurnal Teknologi Pertanian Andalas, 22(1), 96-101.

Thøgersen, J., de Barcellos, M. D., Perin, M. G., \& Zhou, Y. (2015). Consumer buying motives and attitudes towards organic food in two emerging markets: China and Brazil. International Marketing Review, 32(3/4), 389-413.

Tu, Y., Yang, Z., \& Ma, C. (2015). Touching tastes: The haptic perception transfer of liquid food packaging materials. Food Quality and Preference, 39, 124-130.

Xie, B., Wang, L., Yang, H., Wang, Y., \& Zhang, M. (2015). Consumer perceptions and attitudes of organic food products in eastern China. British Food Journal, 117(3), 11051121. https://doi.org/10.1108/BFJ-09-2013-0255

Yazdanpanah, M., \& Forouzani, M. (2015). Application of the Theory of Planned Behaviour to predict Iranian students' intention to purchase organic food. Journal of Cleaner Production, 107, 342-352. 